\title{
ORIL-824
}

Contract No. W-7405, eng 26

REACTOR TECHNOLOGY DIVISION

Section IV - Engineering Materials

\section{THE CORROSION OF MINLATURB FUEL PLATES IN SIMULATED REACTOR COOLING WATER}

James L. Bnglish

Date Issued DEC 181950

OAK RIDGE NATIONAL IABORATORY operated by CARBIDE AND CARBON CHEMICALS DIVISION Union Carbide and Carbon Corporation Post Orfice Box P Oak R1dge, Tennessee

Photostat Price \$

480

Microfilm Price 2.70

Available from the

Office of Technical Services

Department of Commerce

Washington 25, D. C. 


\section{-3-}

\section{TABLE OF CONTEENIS}

1.0 INTRODUCTION

Page

2.0 ABSTRACT

5

3.0 TEST MATERIALS

6

4.0 TEST CONDITIONS

7

5.0 CORROSION DATA

6.0 DISCUSSION OF DATA

7.0 CONCLUSION

19

8.0 ACKNOWLEDGEMERNTS 


\section{-4- \\ LIST OF TABLES AND FIGURES}

I Number of P1ts Observed on Fuel P1ates Exposed to $0.005 \mathrm{M}$ Eydrogen Peroxide at $85^{\circ} \mathrm{C}$.

II Maximum P1t Depths Observed on Fuel Plates Exposed to $0.005 \mathrm{M}$ Hydrogen Peroxide at $85^{\circ} \mathrm{C}$.

III Maximum P1t Diameters Observed on Fuel Plates Exposed to $0.005 \mathrm{M}$ Hydrogen Peroxide at $85^{\circ} \mathrm{C}$.

IV Incremental Weight Changes on Fuel Plates Exposed to $0.005 \mathrm{M}$ Hydrogen Peroxide at $85^{\circ} \mathrm{C}$.

Cumulative Weight Changes and Corrosion Rates on Fuel

VI The Percent Increase in the Average Number of P1ts Formed on Fuel Plates as a Function of Bxposure Time.

vII Average Maximum and Actual Maximum P1t Depths Observed on Fuel Plates in $0.005 \mathrm{M}$ Hydrogen Peroxide at $85^{\circ} \mathrm{C}$.

VIII Average Incremental We1ght Changes Observed on Fuel Plates Exposed to $0.005 \mathrm{M}$ Hydrogen Peroxide at $85^{\circ} \mathrm{C}$.

IX Average Cumulative Weight Changes Observed on Fuel Plates Exposed to $0.005 \mathrm{M}$ Hydrogen Peroxide at $85^{\circ} \mathrm{C}$.

X-1,2 Photographs of Fuel Plates Prior to Corrosion Test.

XI-1, 2 Photographs of Fuel Plates After 1 Month's Exposure to $0.005 \mathrm{M}$ Hydrogen Peroxide at $85^{\circ} \mathrm{C}$.

XII-1;2 Photographs of Fuel Plates After 2 Month's Exposure to $0.005 \mathrm{M}$ Hydrogen Peroxide at $85^{\circ} \mathrm{C}$.

XIII-1, 2 Photographs of Fuel Plates After 3 Month's Exposure to $0.005 \mathrm{M}$ Hydrogen Peroxide at $85^{\circ} \mathrm{C}$. 
This report is issued as one of a series of reports concerned with corrosion studies for the Materials Testing Reactor. The corrosion resistance of miniature fuel plates in simulated reactor cooling water was investigated and the results are included herewith. The fuel plate samples were prepared by C. D. Smith of the Metallurgy Division at Oak Ridge National Laboratory. The purpose of this investigation was twofold; 1) to determine the effect of various practices for fuel plate fabrication on corrosion resistance, and 2) to determine the extent of penetration of the fuel plates by localized corrosion attack.

\subsection{ABSTRACT}

The corrosion resistance of miniature fuel plates vas evaluated in $0.005 \mathrm{M}$ hydrogen peroxide at $85^{\circ} \mathrm{C}$. The individual piates consisted of an uranium-aluminum core clad with a layer of as aluminum and 725 aluminum. The fuel plate samples were in four groups, each of which represented a different processing practice in the fabrication of fuel plate assemblies. The corrosion test was conducted for 3 months with monthly sample inspections. All four groups of samples exhibitiad good corrosion resistance during the first month of exposure, but localized corrosion attack became prominent on several groups during the last two months of the test. Corrosion rates, calculated on the assuration that corrosion was of a uniform nature, were $0.18 \mathrm{mil} /$ year and less on all groups at the end of 3 months. Of major signiflcance, however, was the formation and development of pitting attack. Test results and data indicete that penetration of the protective aluminum cladalng to the uraniumaluminum core occirred in one instance. Specimens prepared by hot rolling followed by cold rolling exhibited the best resistance to localized corrosion attack of the four groups. These samples were designated as Group 1. The maximum pit depth observed on the samples after 3 months was 8.4 mils. Semples in Group 4 showed the next best corrosion resistance; maximum pit penetration on these specimens was $10.0 \mathrm{mils}$ after 3 months. The most severe penetration, $17.6 \mathrm{mils}$, was observed on specinens in Groups 2 and 3 after 3 months of exposure. 


\subsection{TEST MATERIALS}

Twelve samples of miniature fuel plates were received representing four fabrication practices. Triplicate specimens for each practice were subjected to corrosion tests. The individual samples were approximately 1 inch vide $\times 4.3$ inches long $x \cdot 0.053-0.064$ inch thick. The core of each specimen contained a $13 \%$ uranium-aluminum alloy which was elad on all sides with layers of as aluminum and 72S aluminum, respectively. The inner core alloy was at least $1 / 4$ inch from the edges on all sides of the specimen.

Four methods for preparation of the samples were used. These were as follows:

1) Group 1 - Regular Practice
a) Hot rolled to 0.070 inch
b) Cold rolled to 0.064 inch

2) Group 2 - Modified Practice
a). Hot rolled to 0.070 inch
b) Cold rolled to 0.064 inch
c) Fluxed; heated at $1100^{\circ} \mathrm{F}$

3) Group 3 - Modified Practice Plus Cold Roll
a) Hot rolled to 0.070 inch
b) Cold rolled to $0.06 \mathrm{~h}$. Inch
c) Fluxed; heated at $1100 \%$
d) Cleaned
e) Cold rolled to 0.053 inch

4) Group 4 - Modified Bractice Plus Cold Roll and Brazing
a) Hot rolled to 0.070 inch
b) Cold rolled to 0.064 inch
c) Fluxed; heated at $1100^{\circ} \mathrm{F}$; cleaned
d) Cold rolled to $0.0531 \mathrm{nch}$
e) Annealed 2 hours at $1100 \% \mathrm{~F}$
f) Bdges fluxed
B) Subjected to regular brazing cycle
h.) Cleaned

In each group of specimens, the core alloy was one-third of thetotal thickness of the plates. The thickness ratio of 725 aluminum to $2 S$ aluminum claddings was $1: 2$. Approximate thicknesses for the component layers of the fuel plates were: 


$$
-7-
$$

Groups 1 and 2: Total thickness -0.064 inch

$$
\begin{array}{lll}
\text { Uranium-aluminum core } & 0.021 & \text { inch } \\
\text { 2S aluminum (each side) } & 0.014 & \text { " } \\
\text { T2S aluminum (each side) } & 0.007
\end{array}
$$

Groups 3 and 4: Total thickness - 0.053 inch

$$
\begin{array}{ll}
\text { Uranium-aluminum core } & 0.018 \text { inch } \\
\text { 2S aluminum (each side) } & 0.012 " ~ \\
72 S \text { aluminum (each side) } & 0.006
\end{array}
$$

\subsection{TEST CONDITIONS}

Demineralized water containing $0.005 \mathrm{M}$ hydrogen peroxide was used as the corrosion test medium. The water $\mathrm{pH}$ was adjusted regularly between 5.5 and 6.5 . The temperature of the water was maintained at $85^{\circ} \mathrm{C} \pm 1^{\circ} \mathrm{C}$. Hydrogen peroxide vas added at 4 hour intervals during the course of the test in order to keep the concentration near $0.005 \mathrm{M}$. Daily peroxide and $\mathrm{pH}$ determinations were made. Solution agitation was accomplished by means of an electrically operated stirrer.

The samples were inspected prior to test for measurement of pit depths and diameters. The samples were then degreased, washed in acetone and alcohol, arled at $110^{\circ} \mathrm{C}$, and weighed.

The total time of the test was 3 months. Samples vere removed at monthly intervals for measurement of corrosion damage.

\subsection{CORROSION DATA}

Photographs of the four groups of specimens were made prior to the corrosilion test and at each monthly inspection period. P1t counts, maximum pit depths and diamieters, and veight changes on the specimens were determined at one month intervals. These data appear in the following te? ises. 


\begin{tabular}{|c|c|c|c|c|c|}
\hline \multirow[b]{2}{*}{ Group } & \multicolumn{4}{|c|}{$\frac{\text { MUMBER OF PITS OBSERVED ON FUEL PLATES EXXPOSE }}{\frac{.00 .005 \mathrm{M} \text { HYDROGEIN PEROXIDE AT } 85^{\circ} \mathrm{C}}{}}$} & \multirow[b]{2}{*}{ 3rd Month } \\
\hline & Sarple & Initial & 1st Month & 2nd Month & \\
\hline 1 & $\begin{array}{l}1 \\
2 \\
3\end{array}$ & $\begin{array}{r}N 11 \\
39 \\
4\end{array}$ & $\begin{array}{r}N 11 \\
39 \\
4\end{array}$ & $\begin{array}{r}38 \\
42 \\
4\end{array}$ & $\begin{array}{l}38 \\
48 \\
60\end{array}$ \\
\hline 2 & $\begin{array}{l}1 \\
2 \\
3\end{array}$ & $\begin{array}{l}\text { Num.* } \\
2 \\
\text { Num. }\end{array}$ & $\begin{array}{l}\text { Num. } \\
2 \\
\text { Num. }\end{array}$ & $\begin{array}{r}7 \\
15 \\
8\end{array}$ & $\begin{array}{l}18 \\
21 \\
16\end{array}$ \\
\hline 3 & $\begin{array}{l}1 \\
2 \\
3\end{array}$ & $\begin{array}{l}3 \\
\text { Num. } \\
\text { Num. }\end{array}$ & $\begin{array}{l}3 \\
\text { Num. } \\
\text { Num. }\end{array}$ & $\begin{array}{r}16 \\
7 \\
3\end{array}$ & $\begin{array}{r}110 \\
24 \\
8\end{array}$ \\
\hline 4 & $\begin{array}{l}1 \\
2 \\
3\end{array}$ & $\begin{array}{l}\text { Num. } \\
\text { Num. } \\
\text { Num. }\end{array}$ & $\begin{array}{l}\text { Num. } \\
\text { Num. } \\
\text { Num. }\end{array}$ & $\begin{array}{l}\text { Num. } \\
\text { Num. } \\
\text { Num. }\end{array}$ & $\begin{array}{l}\text { Num. } \\
\text { Num. } \\
\text { Num. }\end{array}$ \\
\hline
\end{tabular}

*Numerous, extremely shallow p1ts; not countable by naked eye. 


\section{TABLE II}

MAXIMUM PIT DEPTHS (MILS) OBSERVED ON FUEL PLATES EXPOSED TO $0.005 \mathrm{M}$ HYDROGEN PEROXIDE AT $85^{\circ} \mathrm{C}$

\begin{tabular}{|c|c|c|c|c|c|}
\hline Group & Sample & Inttial & 1st Month & 2nd Month & 3 ra Month \\
\hline \multirow[t]{2}{*}{1} & $\begin{array}{l}1 \\
2 \\
3\end{array}$ & $\begin{array}{l}\text { N11 } \\
1.4 \\
1.2 \\
\end{array}$ & $\begin{array}{l}N 11 \\
1.4 \\
1.2 \\
\end{array}$ & $\begin{array}{l}8.4 \\
4.0 \\
1.2 \\
\end{array}$ & $\begin{array}{l}8.4 \\
6.4 \\
1.2 \\
\end{array}$ \\
\hline & Average & 0.9 & 0.9 & 4.5 & 5.3 \\
\hline \multirow[t]{2}{*}{2} & $\begin{array}{l}1 \\
2 \\
3\end{array}$ & $\begin{array}{l}1.6 \\
2.8 \\
1.3 \\
\end{array}$ & $\begin{array}{l}1.6 \\
2.8 \\
1.3 \\
\end{array}$ & $\begin{array}{l}8.8 \\
9.6 \\
7.2 \\
\end{array}$ & $\begin{array}{r}12.0 \\
17.6 \\
9.2 \\
\end{array}$ \\
\hline & Average & 1.9 & 1.9 & 8.5 & 12.9 \\
\hline 3 & $\begin{array}{l}1 . \\
2 \\
3\end{array}$ & $\begin{array}{l}2.4 \\
0.9 \\
0.8 \\
\end{array}$ & $\begin{array}{l}2.4 \\
0.9 \\
0.8 \\
\end{array}$ & $\begin{array}{l}8.0 \\
7.2 \\
8.2 \\
\end{array}$ & $\begin{array}{r}14.0 \\
.8 .8 \\
17.6 \\
\end{array}$ \\
\hline . & Average & 1.4 & 1.4 & 7.8 & 13.5 \\
\hline 4 & $\begin{array}{c}1 \\
2 \\
3 \\
\text { Average }\end{array}$ & $\begin{array}{l}2.4 \\
2.0 \\
3.2 \\
2.5\end{array}$ & $\begin{array}{l}2.4 \\
2.0 \\
3.2 \\
2.5\end{array}$ & $\begin{array}{l}2.4 \\
2.0 \\
3.2 \\
2.5\end{array}$ & $\begin{array}{r}2.6 \\
10.0 \\
4.8 \\
5.8\end{array}$ \\
\hline
\end{tabular}

Note: Approximately 5-10 percent of total number of p1ts were selected for greatest depth; above flgures represent the average maximum p1t depth for this 5-10 percent selected. 
$-10-$

TABLE III

MAXTMOM PIT DIAMEITERS (MIIS) OBSERVIED ON FUEL PLATES EXPOSEDD TO $0.005 \mathrm{M}$ HYDROGEN PEROXIDE AT $85^{\circ} \mathrm{C}$

\begin{tabular}{|c|c|c|c|c|c|}
\hline Group & Sample & Init1al & lst Month & 2nd Month & 3ra Month \\
\hline 1 & $\begin{array}{l}1 \\
2 \\
3\end{array}$ & $\begin{array}{r}\mathbf{N 1 1} \\
28 \\
20\end{array}$ & $\begin{array}{r}\text { N11 } \\
28 \\
20\end{array}$ & $\begin{array}{l}40 \\
28 \\
20\end{array}$ & $\begin{array}{l}40 \\
28 \\
20\end{array}$ \\
\hline 2 & $\begin{array}{l}1 \\
2 \\
3\end{array}$ & $\begin{array}{l}16 \\
20 \\
10\end{array}$ & $\begin{array}{l}50 \\
20 \\
20\end{array}$ & $\begin{array}{l}60 \\
40 \\
20\end{array}$ & $\begin{array}{l}28 \\
40 \\
40\end{array}$ \\
\hline 3 & $\begin{array}{l}1 \\
2 \\
3\end{array}$ & $\begin{array}{l}50 \\
20 \\
20\end{array}$ & $\begin{array}{l}50 \\
20 \\
20\end{array}$ & $\begin{array}{l}60 \\
40 \\
20\end{array}$ & $\begin{array}{l}60 \\
40 \\
20\end{array}$ \\
\hline 4 & $\begin{array}{l}1 \\
2 \\
3\end{array}$ & $\begin{array}{l}10 \\
10 \\
10\end{array}$ & $\begin{array}{l}10 \\
10 \\
10\end{array}$ & $\begin{array}{l}10 \\
20 \\
20\end{array}$ & $\begin{array}{l}10 \\
20 \\
20\end{array}$ \\
\hline
\end{tabular}


TABLE IV

INCREMMGIVTAL WEIGHT CHANGES (MG./DM²) ON FUEL PLATES EXPOSED TO $0.005 \mathrm{M}$ HYDROGEN PEROXIDE AT $85^{\circ} \mathrm{C}$

\begin{tabular}{|c|c|c|c|c|}
\hline Group & Sample & 1st Month & 2nd Month & 3ra Month \\
\hline \multirow[t]{2}{*}{1} & $\begin{array}{l}1 \\
2 \\
3\end{array}$ & $\begin{array}{l}-1.5 \\
-2.0 \\
-0.4 \\
\end{array}$ & $\begin{array}{l}-3.1 \\
-0.8 \\
-2.3 \\
\end{array}$ & $\begin{array}{l}+13.0 \\
+13.6 \\
+\quad 12.1 \\
\end{array}$ \\
\hline & Average & -1.3 & -2.1 & +12.9 \\
\hline \multirow[t]{2}{*}{2} & $\begin{array}{l}1 \\
2 \\
3\end{array}$ & $\begin{array}{r}+7.5 \\
+4.8 \\
+4.6 \\
\end{array}$ & $\begin{array}{l}-0.9 \\
=1.5 \\
-0.4 \\
\end{array}$ & $\begin{array}{r}+0.6 \\
+\quad 5.7 \\
+\quad 1.5 \\
\end{array}$ \\
\hline & Average & +5.6 & -0.9 & +2.6 \\
\hline \multirow[t]{2}{*}{3} & $\begin{array}{l}1 \\
2 \\
3\end{array}$ & $\begin{array}{r}+5.8 \\
+14.4 \\
+12.2 \\
\end{array}$ & $\begin{array}{l}-1.8 \\
-0.7 \\
-0.3 \\
\end{array}$ & $\begin{array}{r}+5.5 \\
-\quad 2.7 \\
+\quad 0.3 \\
\end{array}$ \\
\hline & Average & +10.8 & -0.9 & +1.0 \\
\hline \multirow[t]{2}{*}{4} & $\begin{array}{l}1 \\
2 \\
3\end{array}$ & $\begin{array}{r}+4.6 \\
+12.1 \\
+\quad 9.3 \\
\end{array}$ & $\begin{array}{r}-0.9 \\
+0.9 \\
+0.2 \\
\end{array}$ & $\begin{array}{l}+5.5 \\
-\quad 1.2 \\
-\quad 1.0 \\
\end{array}$ \\
\hline & Average & +8.7 & +0.07 & +1.4 \\
\hline
\end{tabular}




\section{TABLE V}

CUMULATIVE WEIGHF CHANGES AND CORROSION RATESS ON FUER PLATES EXPOSED TO $0.005 \mathrm{M}$ HYDROGEN PEROXIDS AT $85^{\circ} \mathrm{C}$ FOR 3 MONITHS

\begin{tabular}{|c|c|c|c|c|c|}
\hline \multirow[b]{2}{*}{ Grour } & \multirow[b]{2}{*}{ Sarmole } & \multicolumn{2}{|c|}{ As Removed } & \multicolumn{2}{|c|}{ Def1lmed } \\
\hline & & Man: & phe & Mam & 然y \\
\hline 1 & $\begin{array}{l}1 \\
2 \\
3\end{array}$ & $\begin{array}{r}+2.8 \\
+2.8 \\
+3.1 \\
\end{array}$ & $\ddot{m}$ & $\begin{array}{r}N 11 \\
-2.7 \\
-1.3 \\
\end{array}$ & $\begin{array}{r}\text { N11 } \\
0.05 \\
0.02 \\
\end{array}$ \\
\hline & Average & +2.9 & & -1.3 & 0.02 \\
\hline 2 & $\begin{array}{l}1 \\
2 \\
3\end{array}$ & $\begin{array}{r}+2.4 \\
+3.0 \\
+1.9 \\
\end{array}$ & $\bar{m}$ & $\begin{array}{l}-8.2 \\
-9.9 \\
-7.8 \\
\end{array}$ & $\begin{array}{l}0.14 \\
0.17 \\
0.14 \\
\end{array}$ \\
\hline & Average & +2.4 & & -8.6 & 0.15 \\
\hline 3 & $\begin{array}{l}1 \\
2 \\
3\end{array}$ & $\begin{array}{l}+3.2 \\
+3.7 \\
+4.1 \\
\end{array}$ & 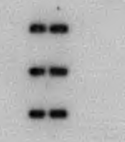 & $\begin{array}{l}-10.0 \\
-10.0 \\
-6.0 \\
\end{array}$ & $\begin{array}{l}0.18 \\
0.18 \\
0.21 \\
\end{array}$ \\
\hline & Average & +3.7 & & -8.7 & 0.15 \\
\hline 4 & $\begin{array}{l}1 \\
2 \\
3\end{array}$ & $\begin{array}{r}+3.4 \\
+3.9 \\
+2.8 \\
\end{array}$ & $\ddot{-}$ & $\begin{array}{l}-5.0 \\
-0.9 \\
-0.9 \\
\end{array}$ & $\begin{array}{l}0.09 \\
0.02 \\
0.02 \\
\end{array}$ \\
\hline & Average & +3.4 & & -2.3 & 0.04 \\
\hline
\end{tabular}

Notes: Corrosion rates based on defilmed and corrected weight loss and represent a corrosion rate for the outer layer of 725 aluminum.

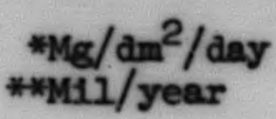




\subsection{DISCUSSION OF DATA}

In general, the distribution and frequency of pits remaritec fairly constant on all groups of specimens during the first month of exposure. However, during the second and third months, definite increase in pit frequencies on all groups was observed with the greatest increase occurring during the third or final month of exposure. Inspection of the four groups prior to exposure disclosed the samples contained in Group 1 to have the best appearance and surface condition. Senple 2 of this group did show 39 p1ts, but these were extremely shallow and barely detectable as pits. The remaining three groups showed numerous. $t$ iny pits which were not of a nature to be counted accurately. The greatest increase in pit frequency was observed on the samples in Group 3 during the third month of exposure. The average percent increase in the number of pits for each group compared to the original number of pits is show below:

\section{PER CEMT INCREASE IN NUMBER OF PITS}

\begin{tabular}{|c|c|c|c|c|}
\hline Groure & $\begin{array}{l}\text { Avg. Initial } \\
\text { No. of Pits } \\
\end{array}$ & let Month & 2nd Month & 3ra Month \\
\hline $\begin{array}{l}1 \\
2 \\
3\end{array}$ & $\begin{array}{r}14 \\
0.7 \\
1.0 \\
-0 . *\end{array}$ & $\begin{array}{l}0 \% \\
0 \\
0 \\
-\cdots\end{array}$ & $\begin{array}{c}100 \% \\
1333 \\
800 \\
-\end{array}$ & $\begin{array}{l}250 \% \\
2430 \\
4600\end{array}$ \\
\hline
\end{tabular}

*Pits too small and numerous to count

The above results for the first three groups are shown graphically In Figure VI as a function of exposure time.

Maximum pit depth measurements vere determined mleroscopically on each specimen in each group. These results are tabulated in Table II. Samples in Group I showed the smallest average maximum pit depth, 5.3 mils, after 3 months exposure; samples in Group 3 shoved the largest average maximum pit depth, 13.5 mils, for the same period of time. The average maximum pit depth for Group 2 vas 12.9 mils; for Group 4 1t was 5.8 mils. In Group 1, the greatest p1t depth measured was 8.4 mils. Since the thickness of the 25 aluminum-72S aluminum clading was 21 mils this indicates a safety factor of two and one-half times before penetration of the inner uranium-aluminum core could occur. In Groun 2, the deepest pit penetration was 17.6 mils which allowed an additional thickness of only $3.4 \mathrm{mils}$ before the inner core would be reached. This maximum pit depth was messured: after an exposure period of 3 months. In Group 3, a maximum pit depth of 17.6 mils was observed also after 3 months of exposure. Th1s penetration is extremely. close to the combined cladding thickness of $18 \mathrm{mils}$ for this group of specimens. During the last month of test. - 


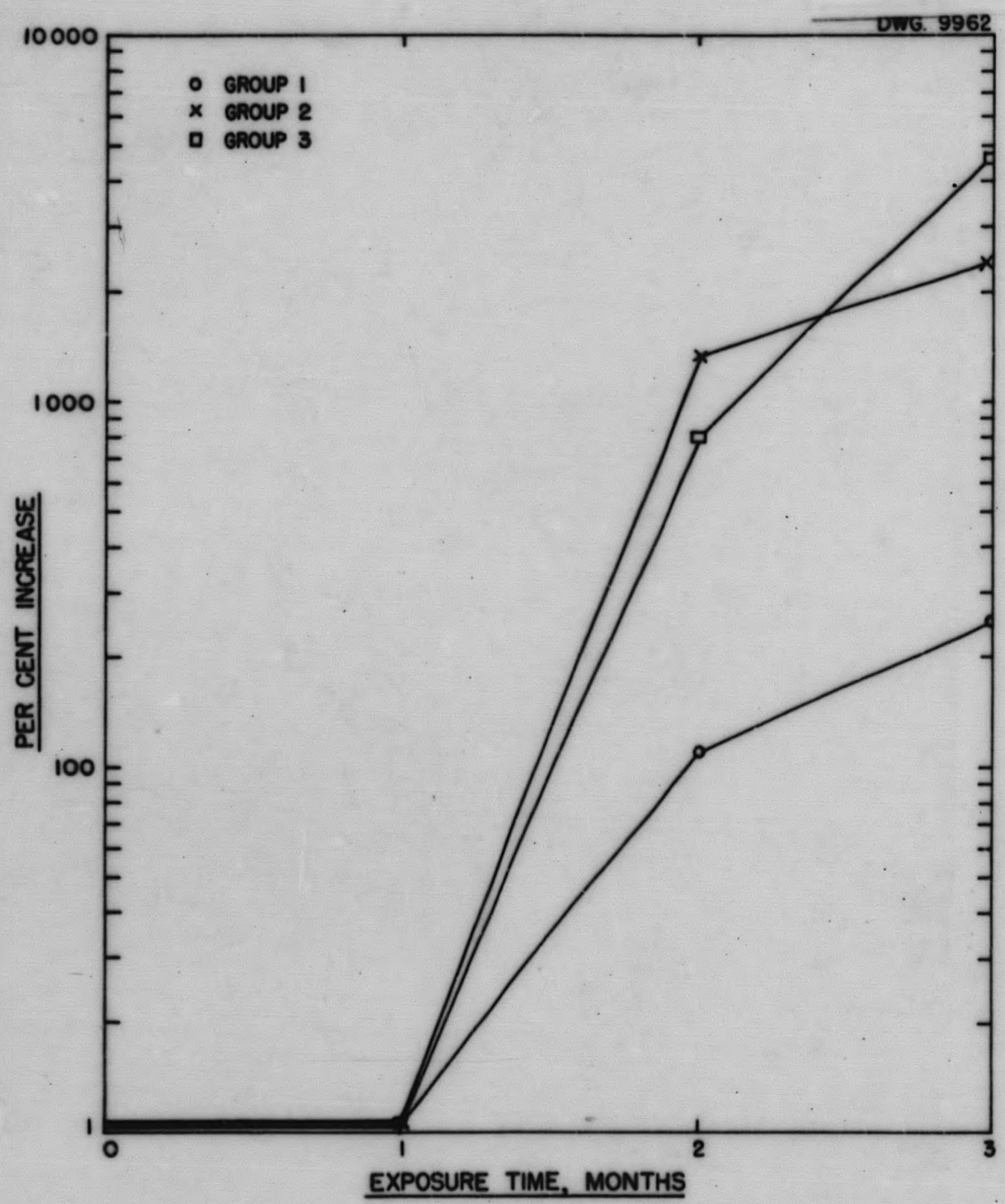

FIG. II THE PER CENT INCREASE IN THE AVERAGE NUMBER OF PITS FORMED ON FUEL PLATES AS A FUNCTION OF EXPOSURE TIME 
a small trace of uranium, $0.001 \mathrm{gm} / 11$ ter, was detected in the vater, indicating that actual penetration of the uranium-aluminum core had occurred. Indieations were that the penetration had.taken place on one or more specimens in Group 3. True misroscopic observations of maximum pit depths were somewhat obscured by the accumulation of corrosion products at the base of the developed pits. Cleaning the specimens to remove these accumulations was not aivays completely successful. Maximum pit penetration observed on the Group 4 specimens was 10 mils after an exposure of 3 months, thus leaving a thickness of 8 mile which had not been penetrated. Summarizing, it should be noted that the maximum pit depths, on all groups, were observed after the third month of exposure. There were no serious pit depths found during the first two months of test. Results of these tests are plotted in Figure VII.

Maximum pit diameters are reported in Table III. These data show that no severe progression in the observed diameters occurred during the 3 months exposure. The diameter of the pits, when one had started, remained fairly constant throughout the course of the test.

The average incremental weight changes on the samples are included in Table IV and Figures VIII. The trend for weight changes in Groups 2, 3, and 4 was similar; an initial veight gain during the first month, a decrease in weight during the second month, snd, finally, a gradual gain in weight during the third and final month of exposure. In Group 1, the specimens exhibited a gradual weight decrease during the first two months followed by an abrupt welght increase. Figure IX presents a comparison of the average cumulative weight changes on the four groups of specimens. In no case was the loss in weight on any of the fuel plate samples of more than minor significance. It should be stated, hovever, that the welght losses are not a direct. result of uniform corrosion attack, but represent in general, the veight 108 due to the metal removed from pits. Then, too, metal loss as a result of pitting is obscured by the veight gains on the samples due to the formation of the protective hydrated aluminum oxide $111 \mathrm{~m}$. Each sample of the four groups exhibited a welght gain at the end of 3 months exposure. In order to determine the equivalent amount of aluminum that entered into combination with oxygen to form the oxide layer, the samples vere cleaned in a mixture of $2 \%$ chromic acid - $5 \%$ phosphoric acid for 20 minutes at $60-70^{\circ} \mathrm{C}$. The equivalent thickness loss of aluminum, mils/year, on the 12 specimens 1s. shown in the last column of Table v. These values are extremely low, $0.18 \mathrm{mil} /$ year and less, and do not represent any significant thickness loss due. to normal corrosion attack. 
$-16-$
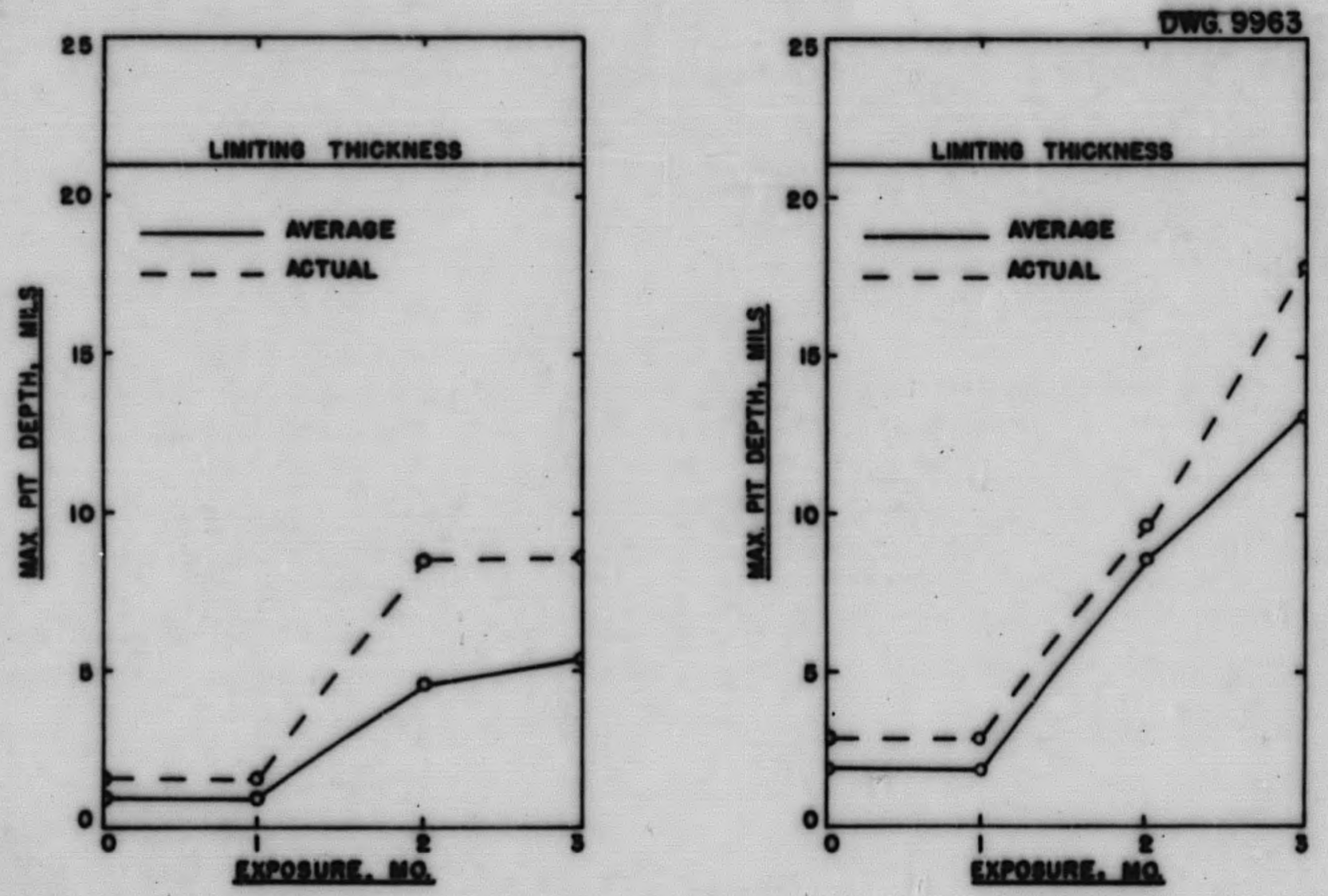

)

A. GROUP I
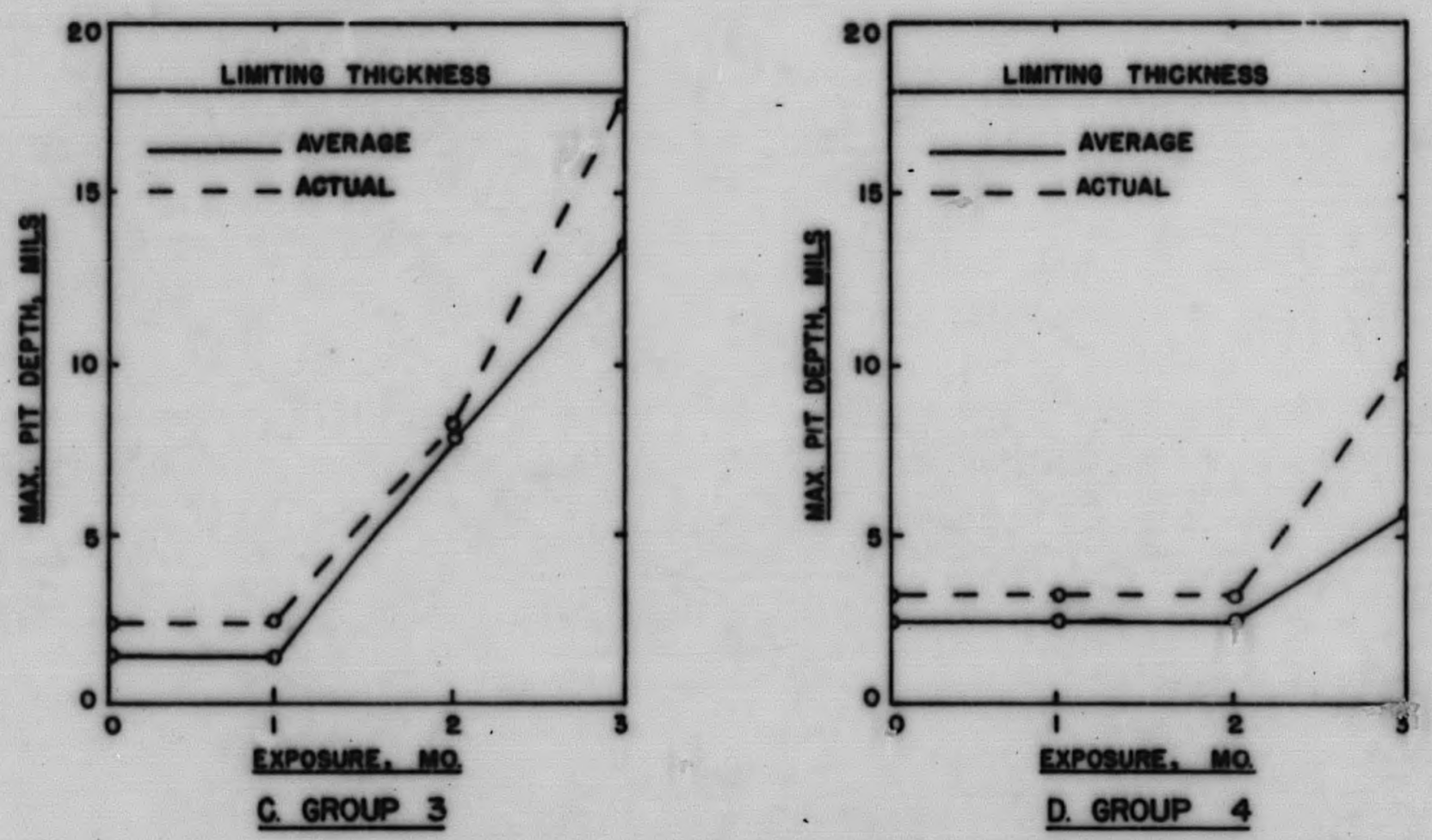

FIG. III AVERAGE MAXIMUM AND ACTUAL MAXIMUM PIT DEPTHS OBSERVED ON FUEL PLATES IN $0.005 \mathrm{M}$ HYDROGEN PEROXIDE AT $85^{\circ} \mathrm{C}$, 


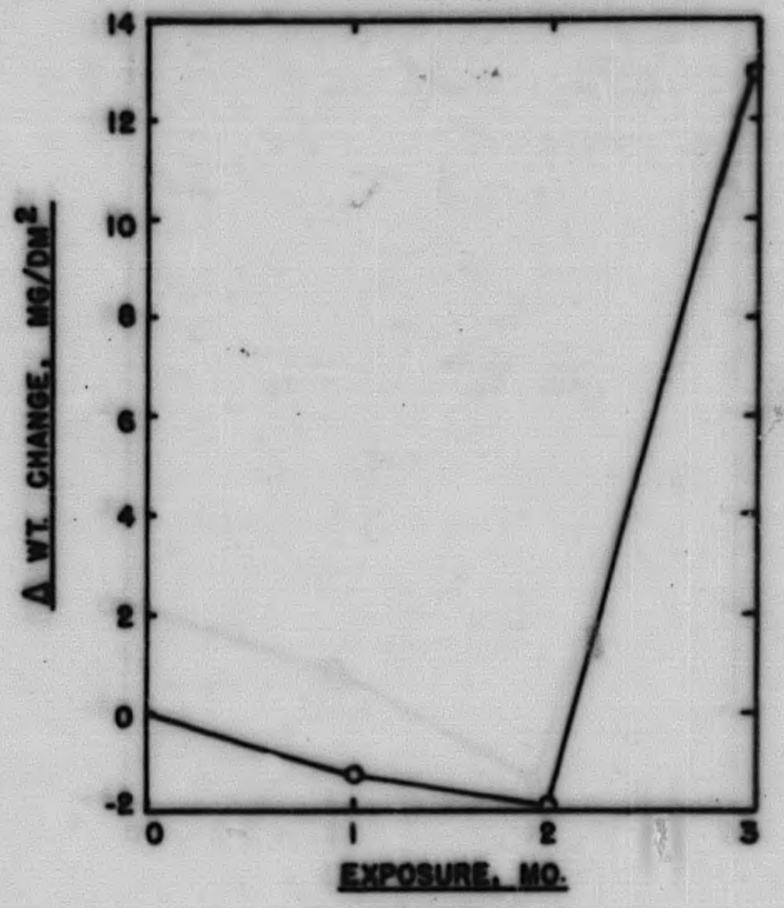

A. GROJP I

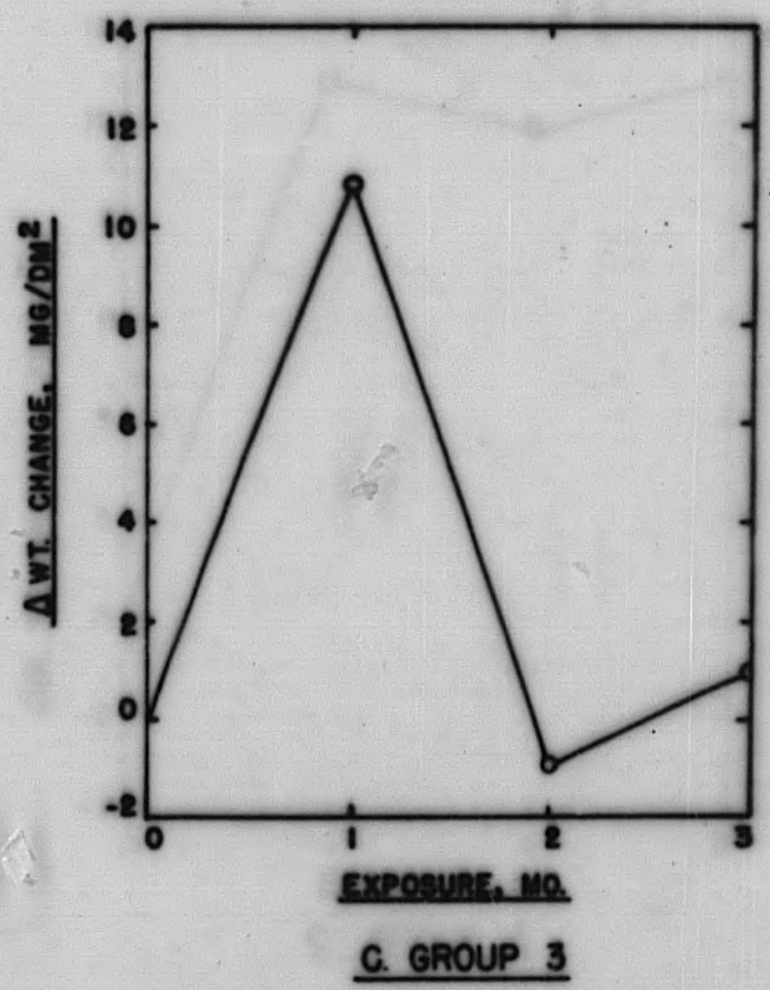

FIG. II AVERAGE INCREMENTAL WEIGHT CHATIGES OBSERVED ON FUEL PLATES EXPOSED TO $0.005 \mathrm{M}$ MYDROGEN PEROXIDE AT $85^{\circ} \mathrm{C}$
DwG. 9964

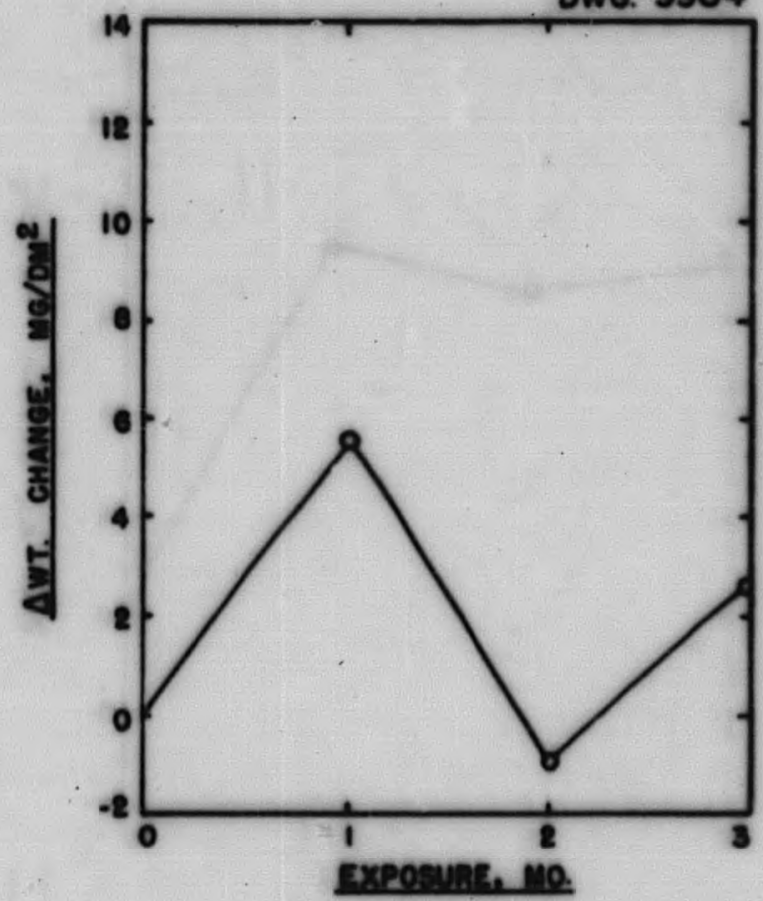

B. GROUP 2

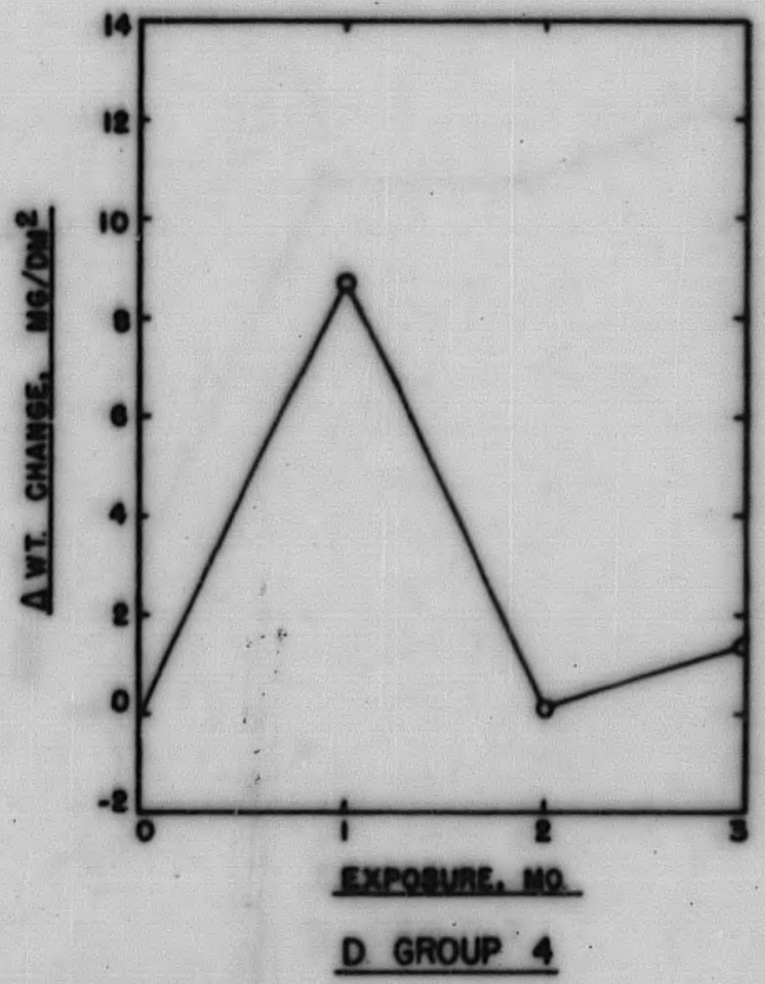




\subsection{CONCLUSION}

The results of these tests indicate that fallure of fuel plates is more apt to occur from the formation and development of localized corrosion (pits) than by normal corrosion attack. Such localized corrosion attack may penetrate through the outer protective cladaing of $2 S$ and $72 S$ aluminum and into the inner uranium-aluminum core material. Th1s penetration can result in the contamination of the cooling water with active material. Contemination of the test medium did occur in this investigation with samples in Group 3 after an exposure period of two months.

Based on overall corrosion performance, samples treated in Groups 1 and 4 exhibited the most satisfactory behavior. Samples In Group 1 exhibited slightly superior behavior to those of Group 4, indicating that the method of processing for Group 1 . was the most successful of the four techniques employed. Samples treated by methods used in Groups 2 and 3 irere not satisfactory and p1t penetration to the core material was evidenced by the presence of uranium in the test water after 2 months exposure.

Photographs of the test specimens appear in Figure X-XIII and

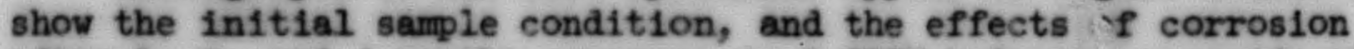
after 1, 2, and 3 months exposure in $0.005 \mathrm{M}$ hydrogen peroxide at $85^{\circ} \mathrm{C}$.

\subsection{ACKMOWLEDGEMEINIS}

The writer wishes to express his appreciation to Miss H. Barker, Mr. S. Wheeler, and Mr. J. Broin, of the Engineering Materials Section, for their assistance in handiline of test specimens and preparing photographs and graphs for this corrosion investigation. 
20

PHOTO NO

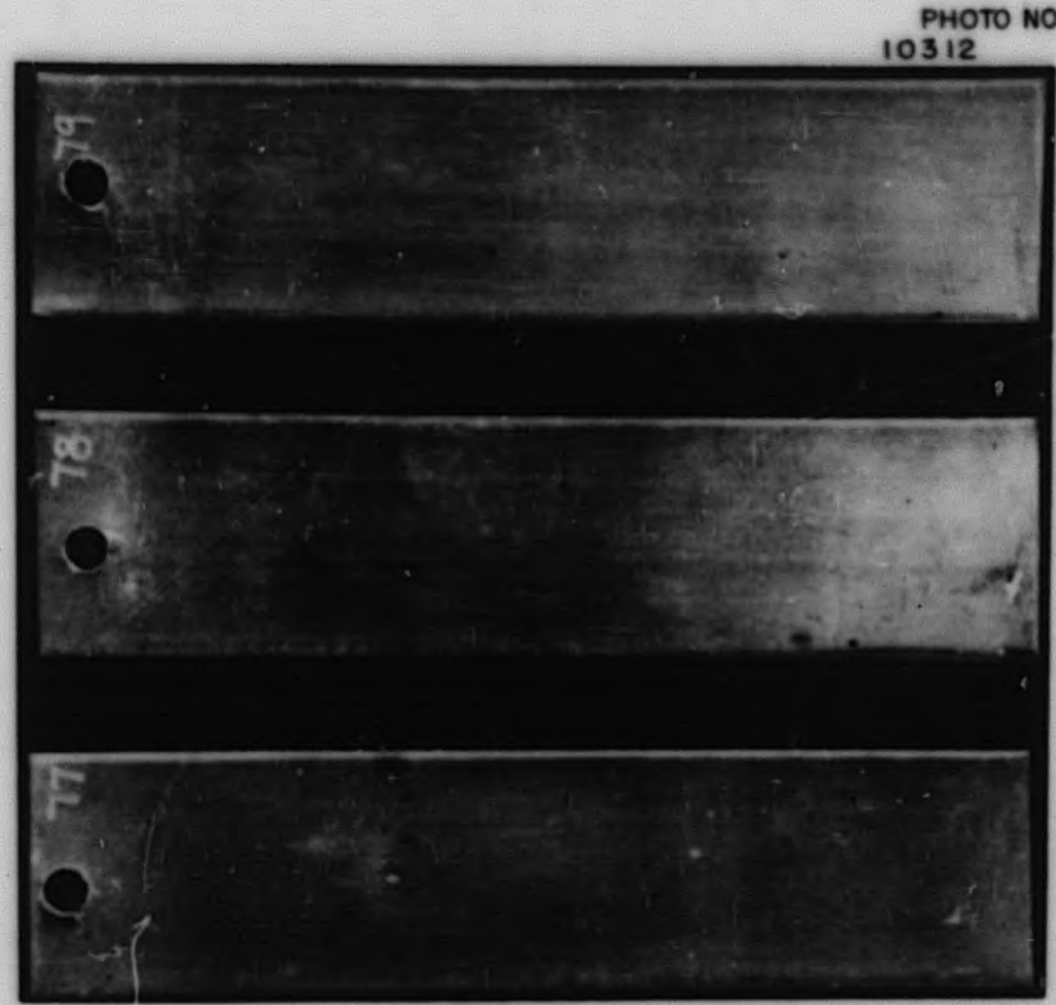

GROUP I

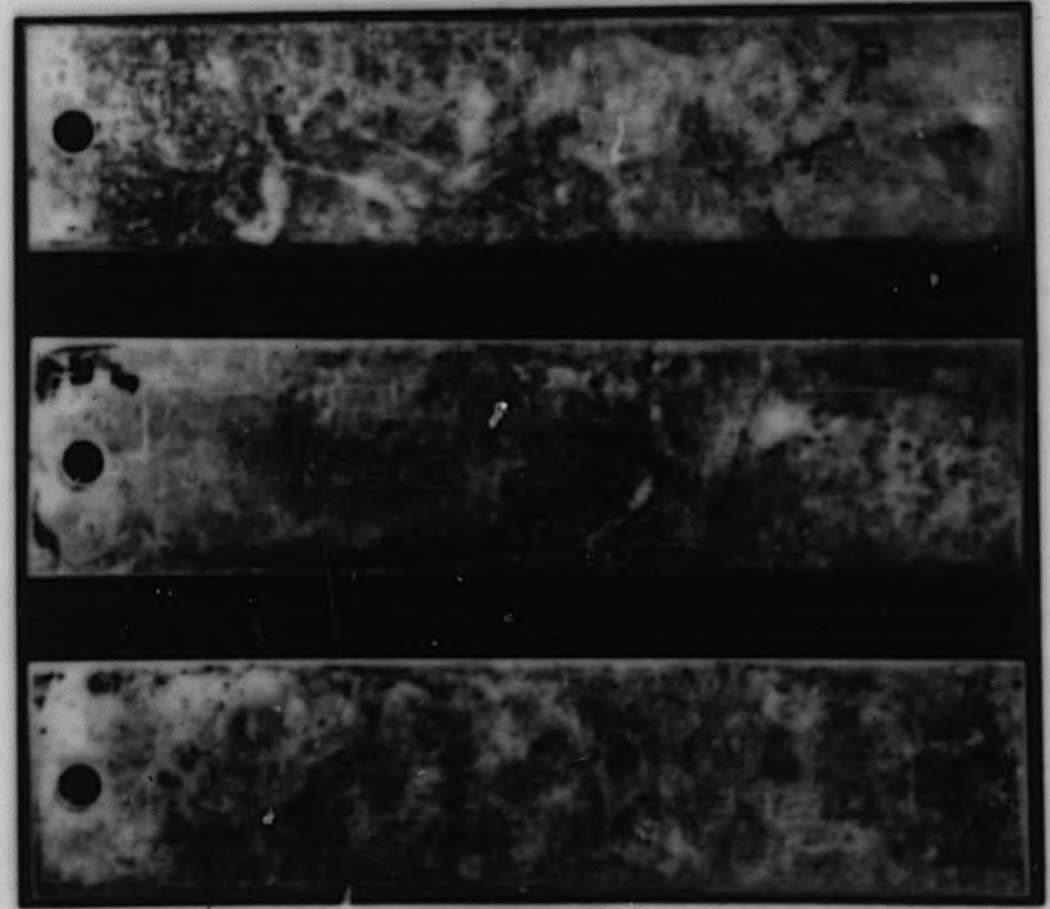

GROUP 2

FIGURE $\mathbf{X}-1$ PHOTOCRAPHS OF MINIATURE FUEL PLATES PRIOR TO EXPOSURE IN SIMULATED COOLING WATER (MAG IX)

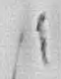




\section{1}

PHOTO NO

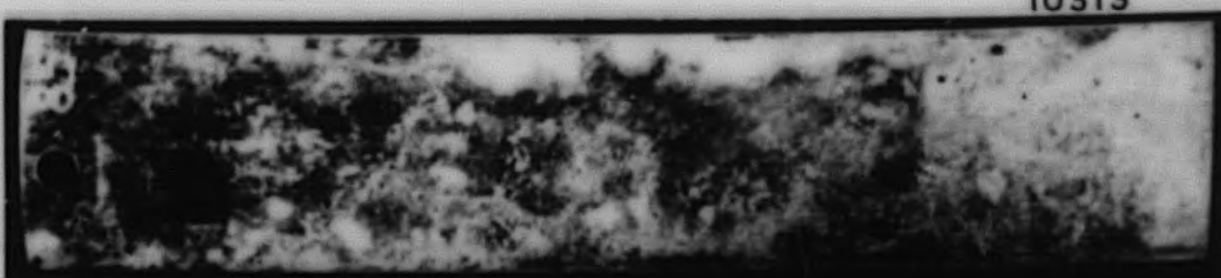

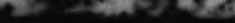
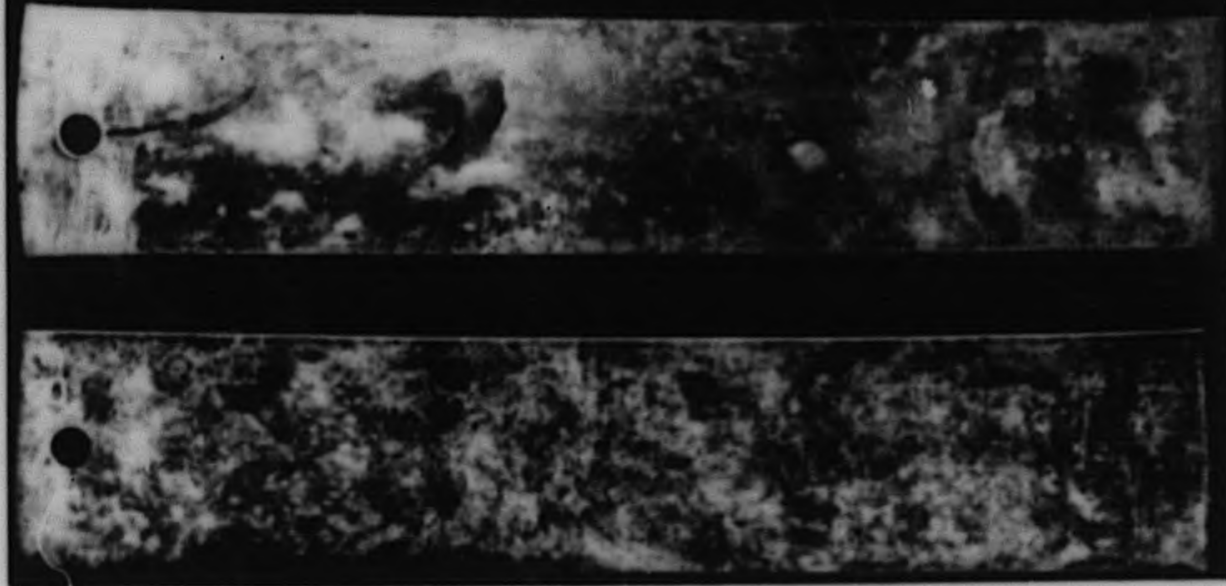

GROUP 3

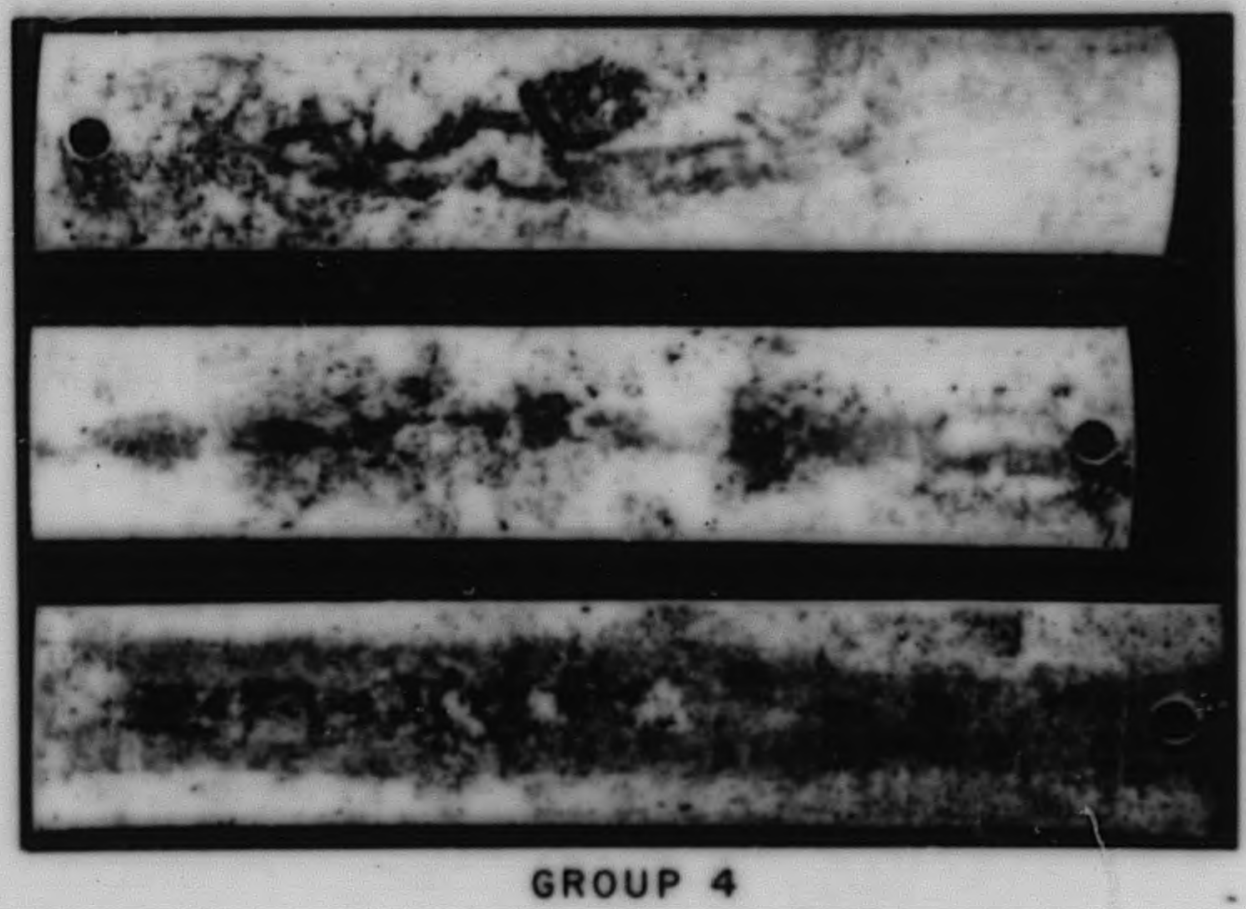

FIGURE $\mathbf{X}-2$ PHOTOGRAPHS OF MINIATURE FUEL PLATES PRIOR TO EXPOSURE IN SIMULATED COOLING WATER (MAG IX) 
22

PHOTO NO

10314
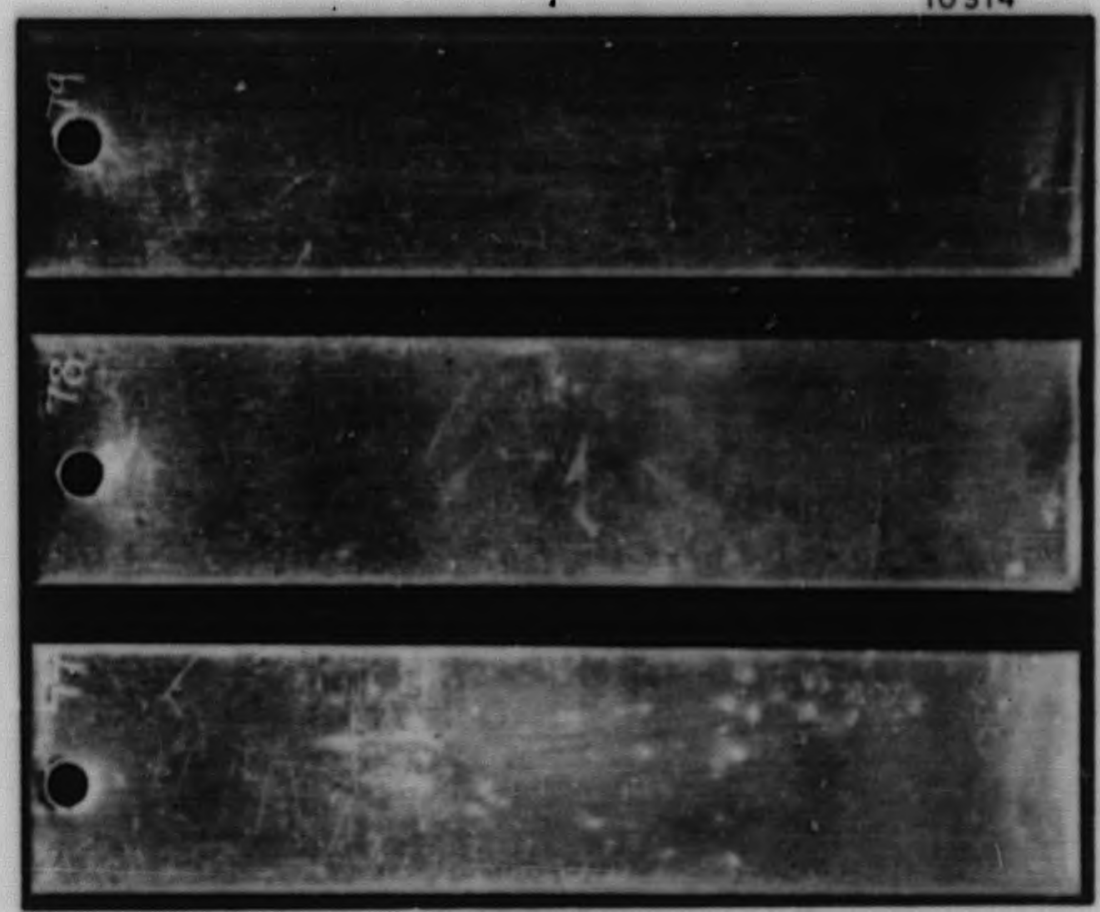

GROUP I

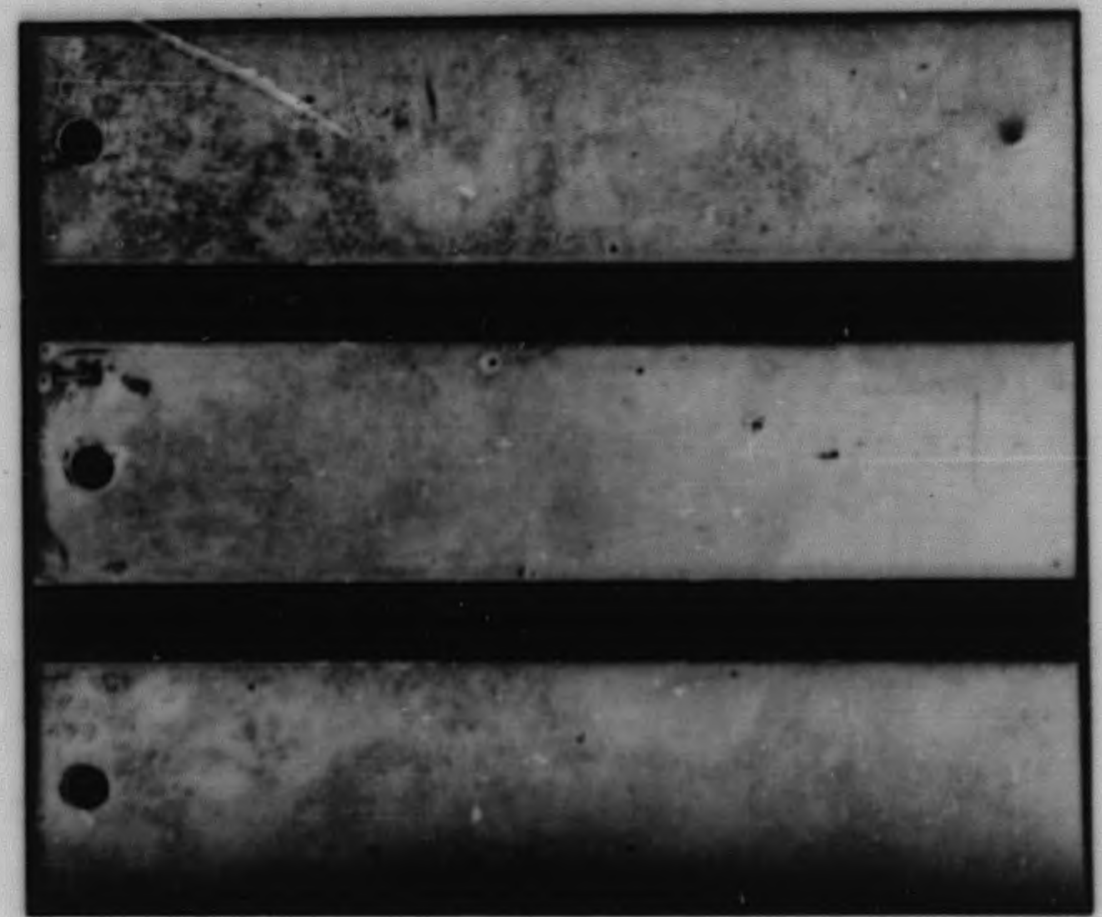

GROUP 2

FIGURE XI-I PHOTOGRAPHS OF MINIATURE FUEL PLATES AFTER I MONTH'S EXPOSURE IN $0.005 \mathrm{M}$ HYDROGEN PEROXIDE AT $85^{\circ}$ (MAG IX) 


\section{3}

PHOTO NO

10315

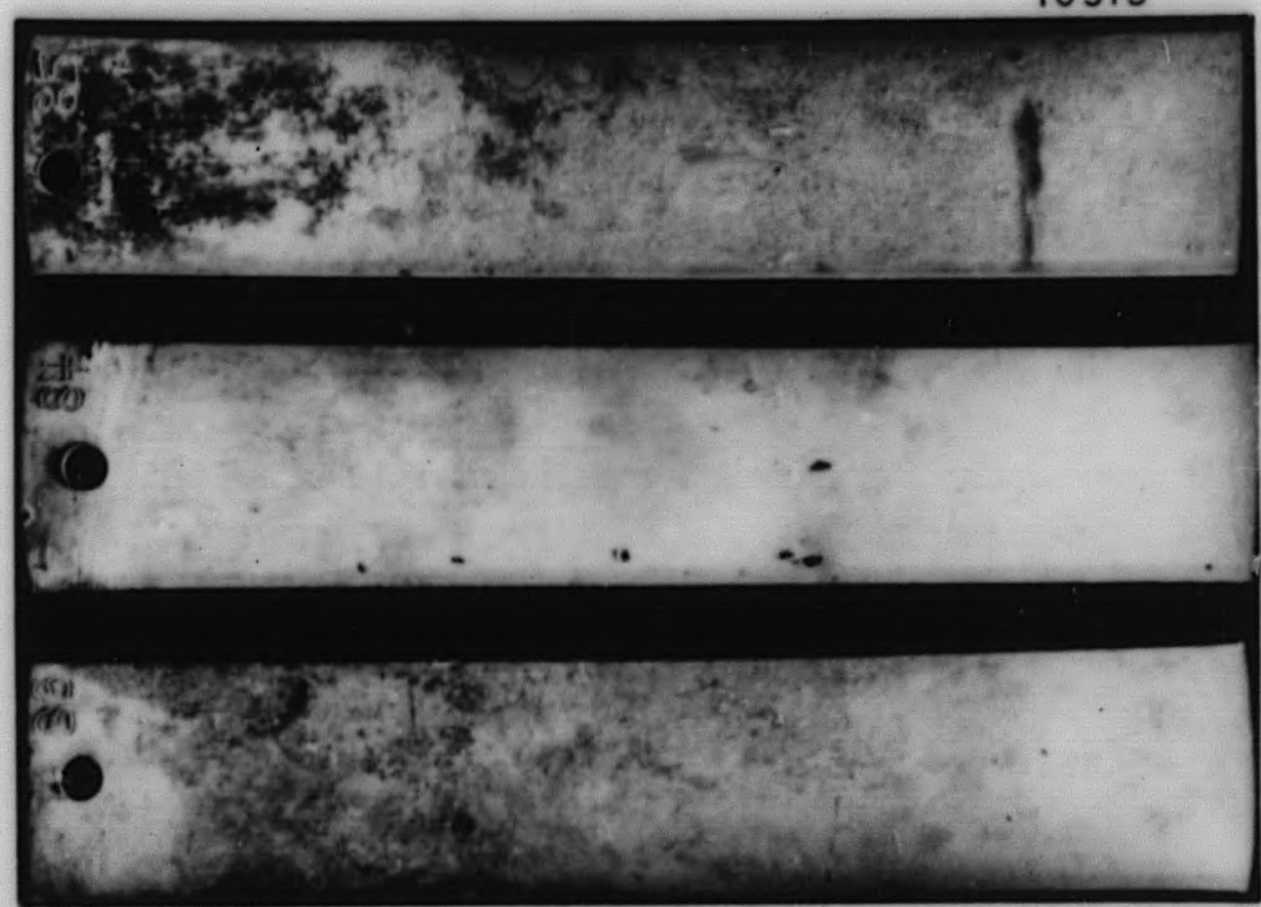

GROUP 3

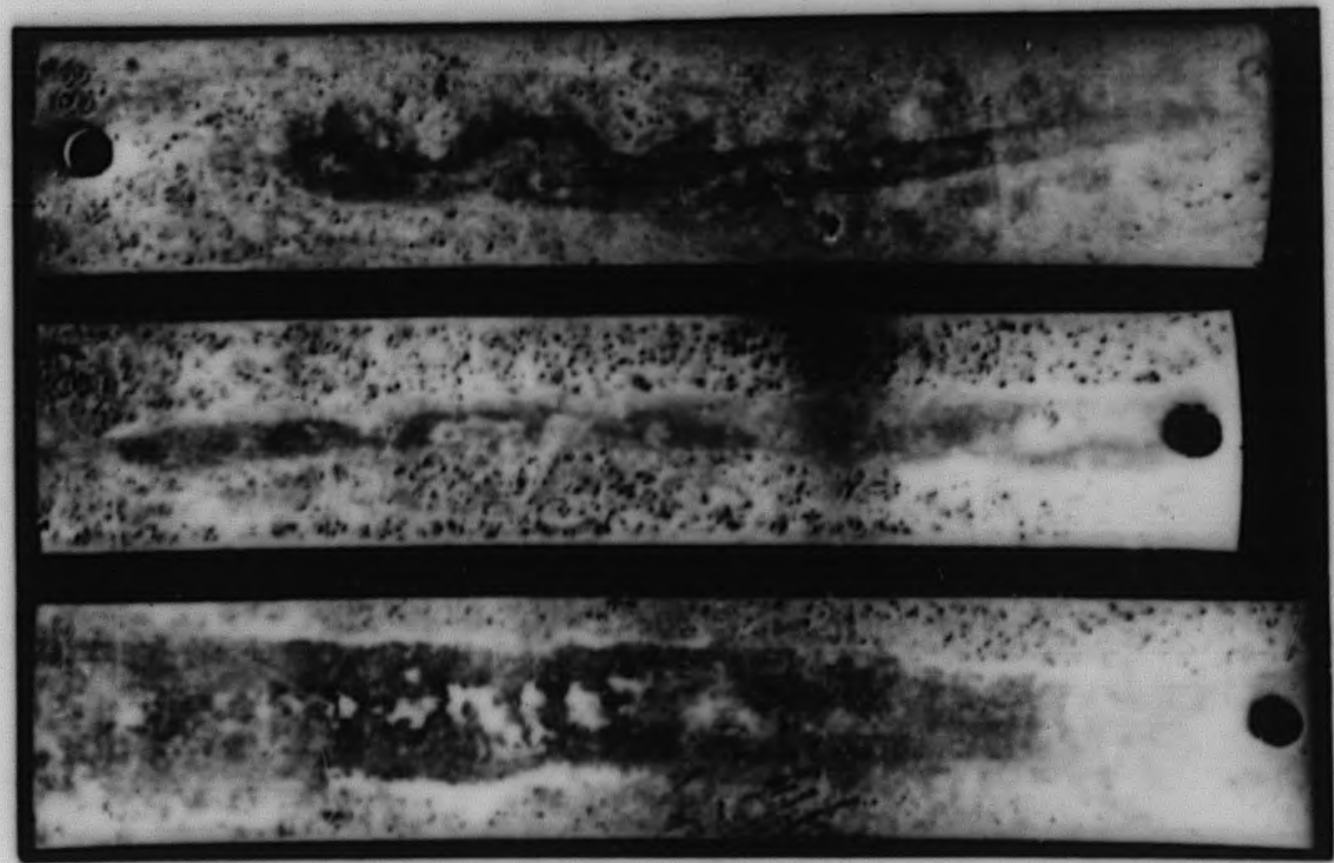

GROUP 4

FIGURE XI-2 PHOTCGRAPHS OF MINIATURE FUEL PLATES AFTER I MONTH'S EXPOSURE IN $0.005 \mathrm{M}$ HYDROGEN 'PEROXIDE AT $85^{\circ} \mathrm{C}$ (MAG IX) 
PHOTO NO

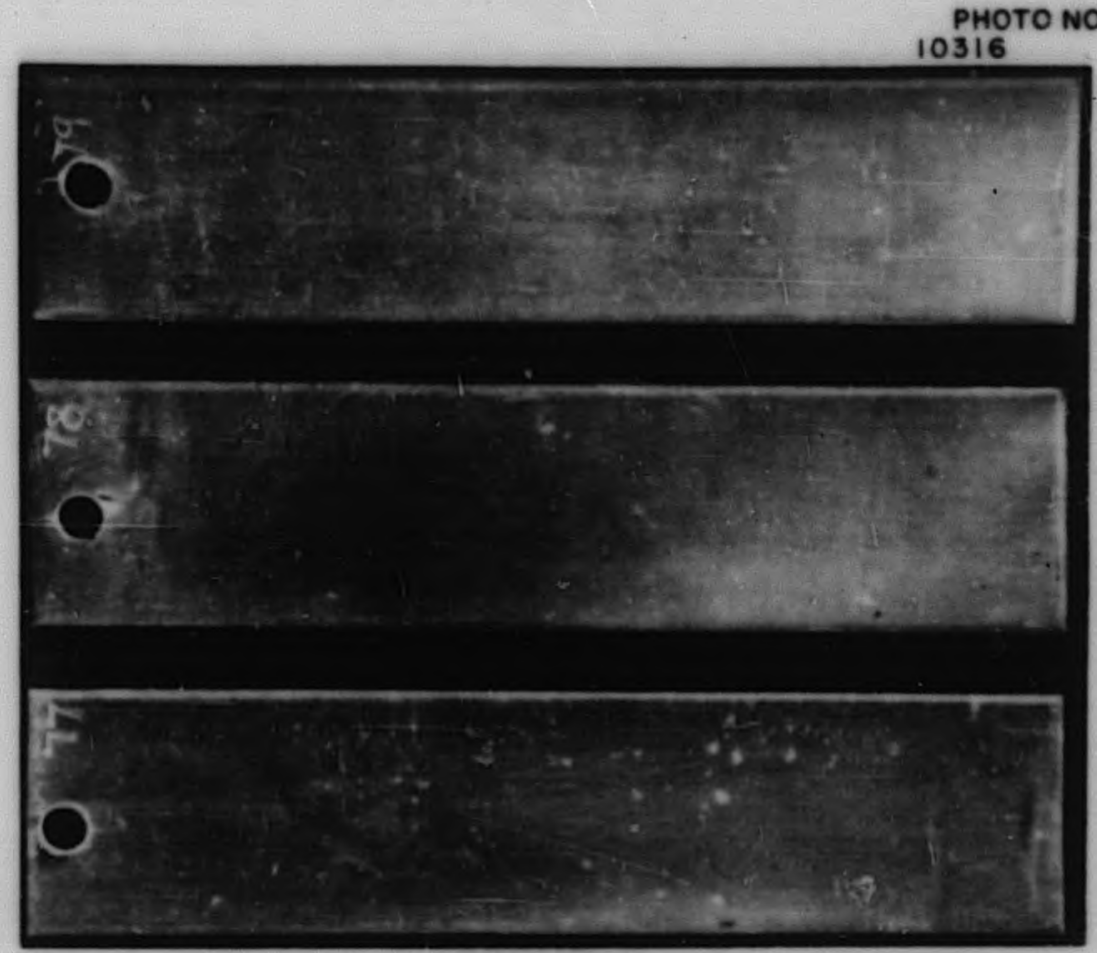

GROUP I

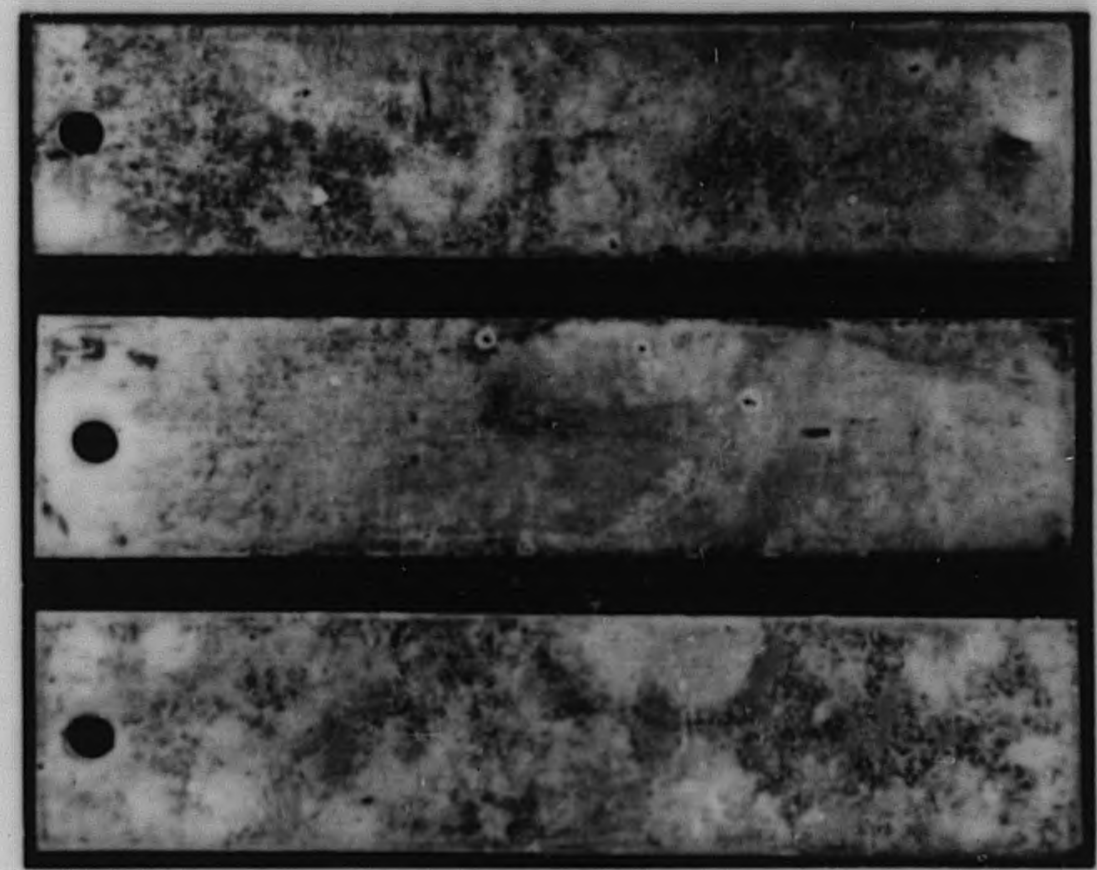

GROUP 2

FIGURE XII-I PHOTOGRAPHS OF MINIATURE FUEL PLATES AFTER 2 MONTH'S EXPOSURE IN $0005 \mathrm{M}$ HYDROGEN PEROXIDE AT $85^{\circ} \mathrm{C}$ (MAG IX) 


\section{5}

PHOTO NO
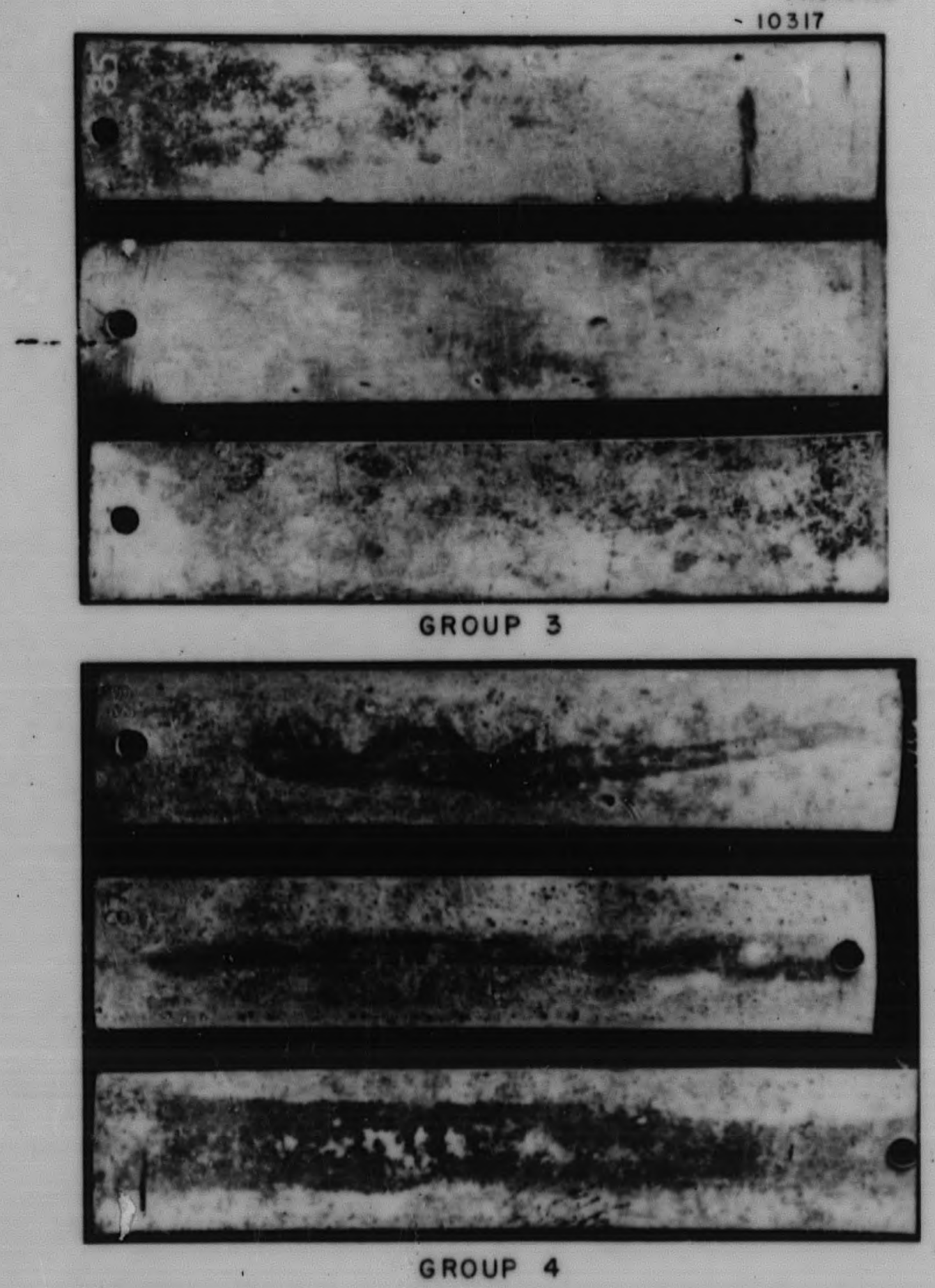

FIGURE XII-2 PHOTOGRAPHS OF MINIATURE FUEL PLATES AFTER 2 MONTH'S EXPOSURE IN $0.005 \mathrm{M}$ HYDROGEN PEROXIDE AT $85^{\circ} \mathrm{C}$ (MAG IX) 


\section{6}

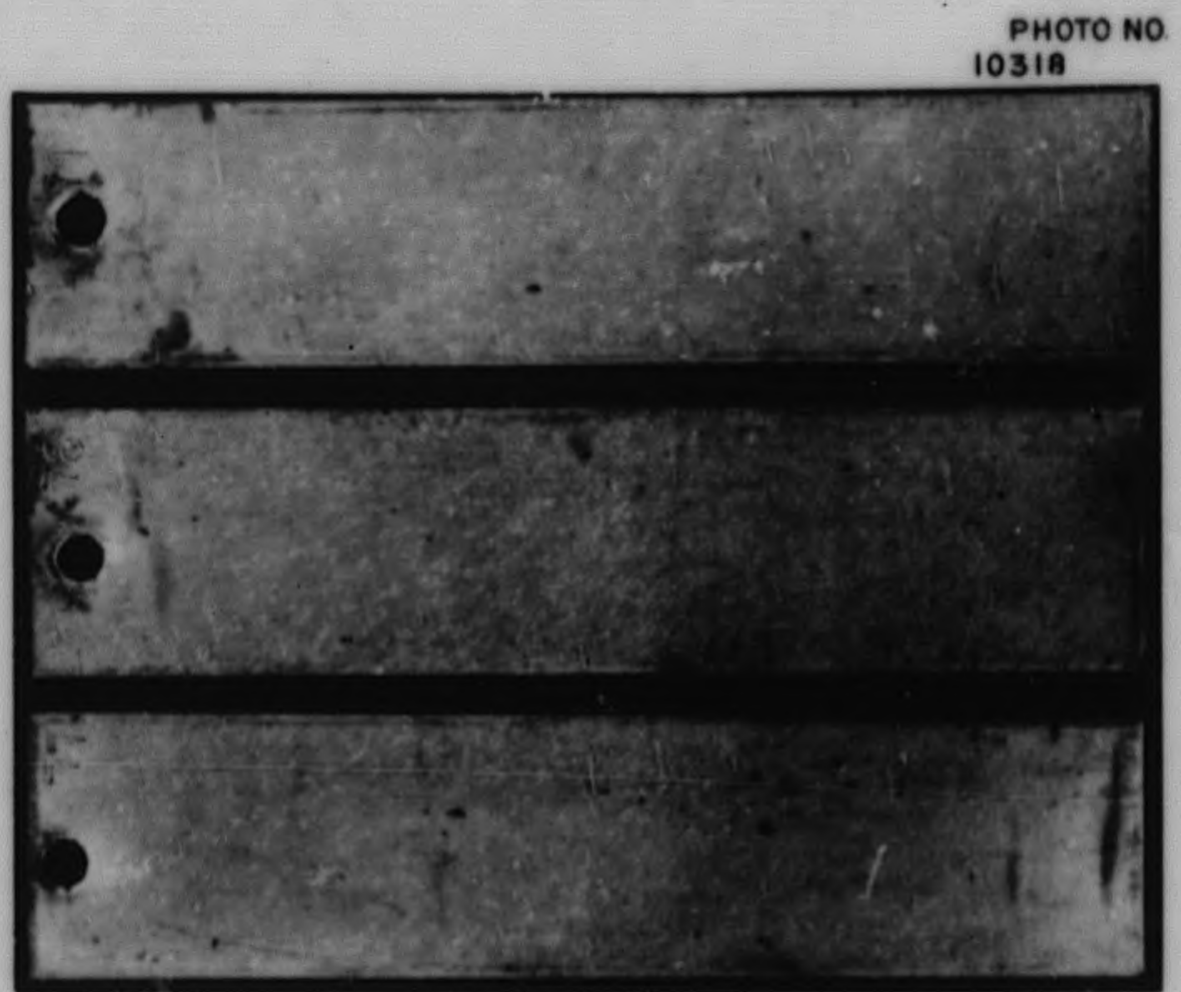

GROUP I

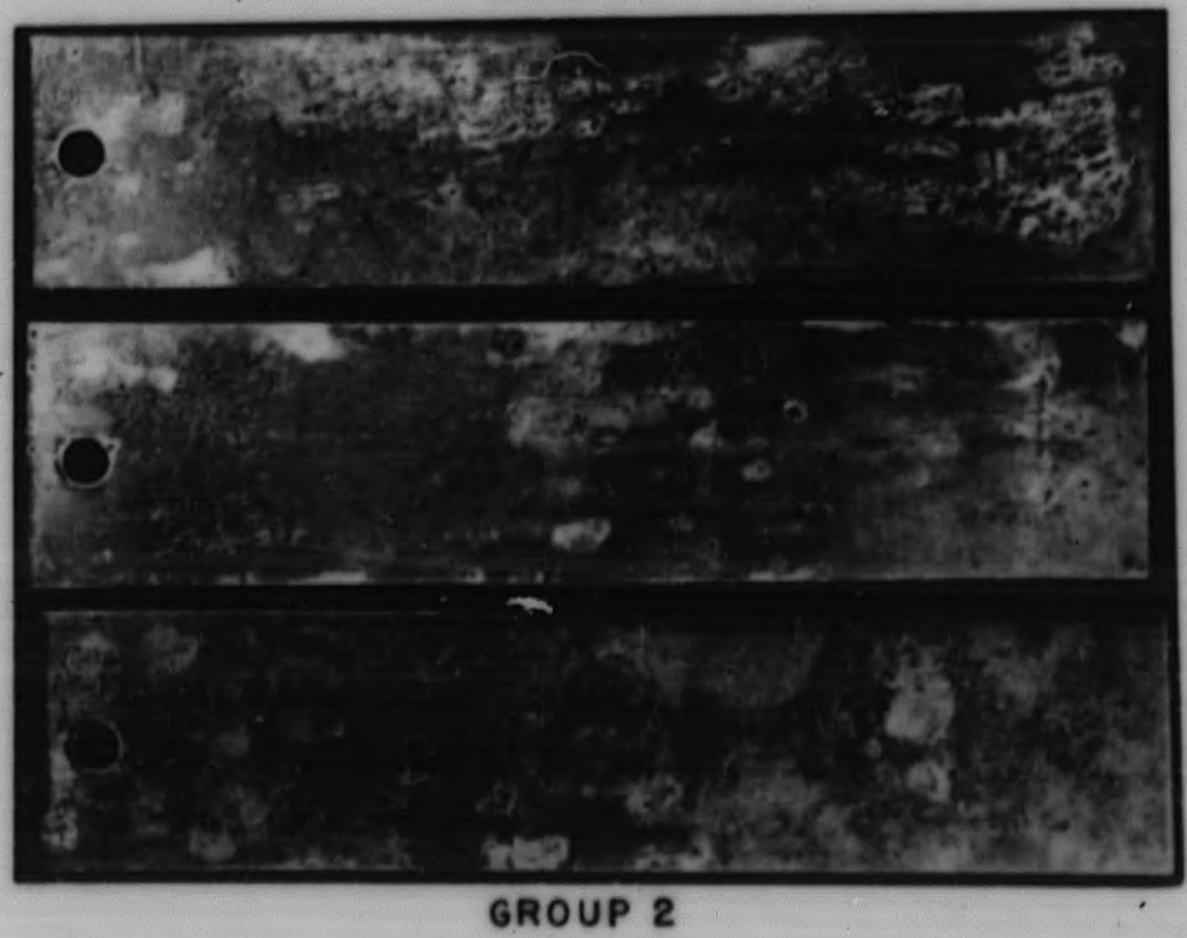

FIGURE XIII-I PHOTOGRAPHS OF MINIATURE FUEL PLATES AFTER 3 MONTH'S EXPOSURE IN 0005 $M$ HYDROGEN PEROXIDE AT $85^{\circ} \mathrm{C}$ (MAG IX) 
27

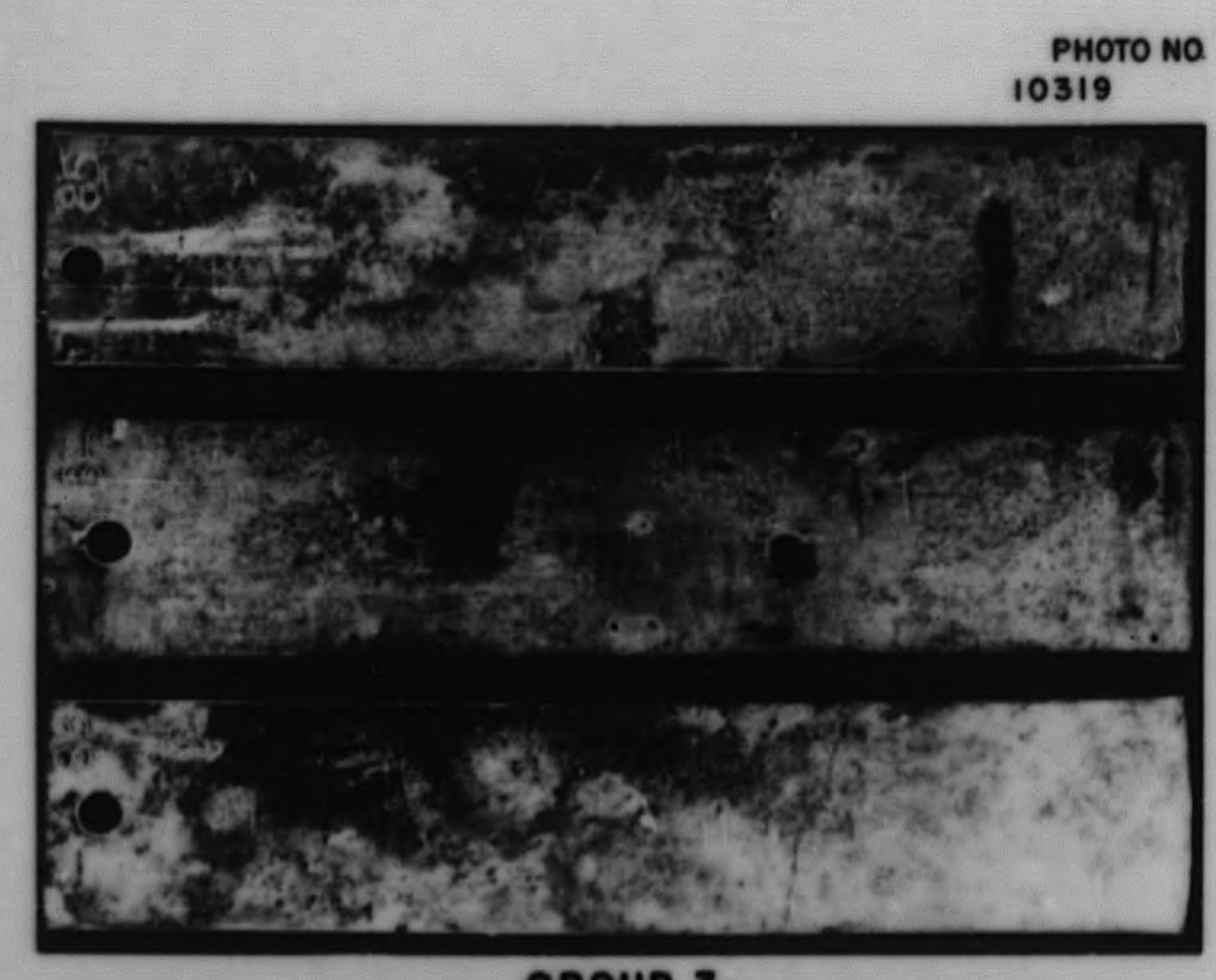

GROUP 3

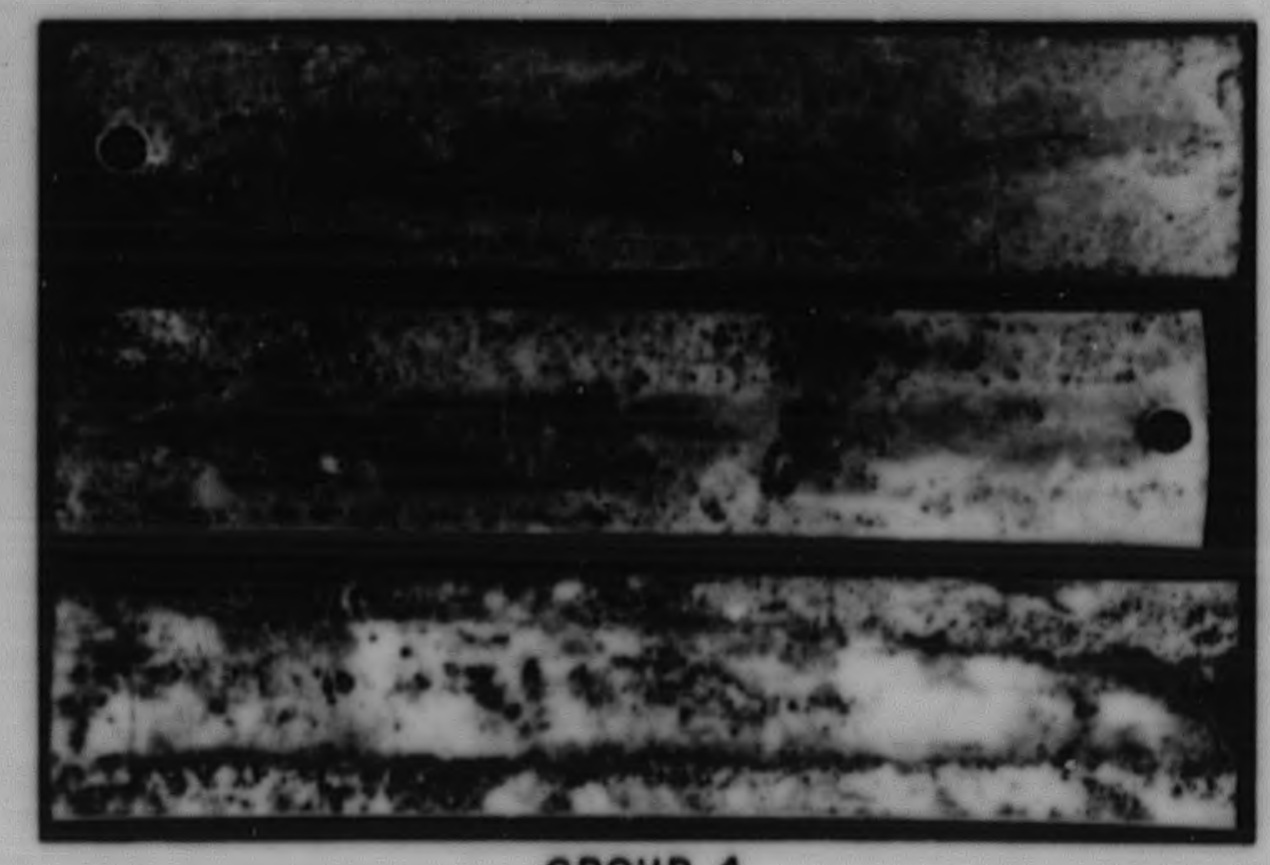

GROUP 4

FIGURE XIII-2 PHOTOGRAPHS OF MINIATURE FUEL PLATES AFTER 3 MONTH'S EXPOSURE IN $0.005 \mathrm{M}$ HYDROGEN PEROXIDE AT $85^{\circ} \mathrm{C}$ (MAG IX)

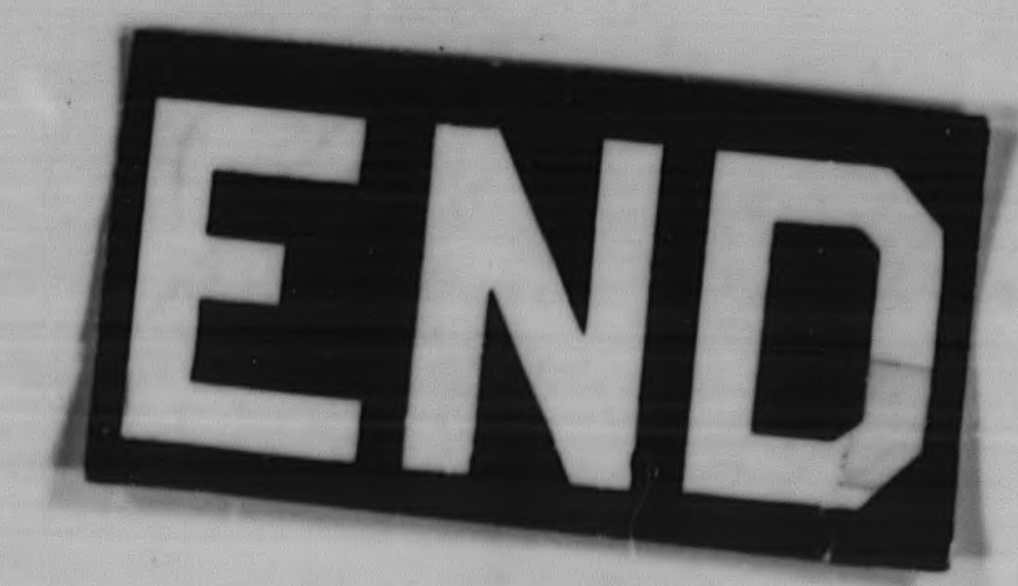

